\title{
A model for germ cell development in a fully segmented worm
}

\author{
Mercedes Maceren-Pates ${ }^{1}$, Yoshihisa Kurita², Gaudioso Pates Jr. ${ }^{1}$ and Michiyasu Yoshikuni ${ }^{1 *}$
}

\begin{abstract}
Introduction: Polychaetes are segmented marine worms with body segments separated by a complete or incomplete septum. In most polychaetes the whole body cavity is filled with gametes during the breeding season. Platynereis dumerilii (PI. dumerilii), which has an incomplete septum was shown to develop a single gonadal structure for gamete production located in the neck region. However, in Perinereis nuntia (Pe. nuntia), which has a complete septum separating each segment, the developmental feature of gametes remains unknown. To clarify this, the marker gene vasa was used to trace the development of germ cells throughout the life stages of Pe. nuntia.

Results: In three-segmented juveniles, Pn-vasa was expressed in the parapodia and in the two cells localized in the pygidium. During the addition of a new segment, Pn-vasa positive cells in the pygidium increased from two to four and two new Pn-vasa positive cells were found in the newly-generated segment. In adults, Pn-vasa was expressed in a large cell cluster at the distal end of the parapodia, in smaller cell clusters (which had an elongated form in the trunk area of the parapodia), and in oocytes in the coelomic cavity. This may suggest that germ cells settle in the parapodia and later translocate into the coelomic cavity to develop into oocytes.
\end{abstract}

Conclusion: Our observations will help in understanding the mechanism of germ cell development in all body segments of Pe. nuntia. We hypothesize that primordial germ cells are supplied from the pygidium to every newly-generating segment which later settle in the parapodium. This will explain how polychaetes can generate gametes in each body segment, even those that are independently separated with a complete septum.

Keywords: Vasa, Perinereis nuntia, Parapodium, Primordial germ cell, Gonad, Septum

\section{Introduction}

Annelids, the segmented worms, are one of the largest and most widely distributed animal phyla. Recent phylogenetic reconstruction of this phylum shows Chaetopteridae, Myzostomida, and Sipuncula branching off from the basal nodes, while the remaining taxa are classified into two clades: Errantia and Sedentaria [1,2]. On the basis of this reconstruction, the ancestral annelid is characterized by a serial division of the body into numerous similar structures also known as homonomous segmentation $[1,3,4]$. Besides segmentation, the presence of a pygidium, pygidial cirri, biramous parapodia and large prostomium are characteristics of the basal taxa [3].

\footnotetext{
* Correspondence: yosikuni@agr.kyushu-u.ac.jp

${ }^{1}$ Fishery Research Laboratory, Kyushu University, 4-46-24 Tsuyazaki, Fukutsu 811-3304, Japan

Full list of author information is available at the end of the article
}

The Nereidid polychaetes (belonging to Errantia) are benthic marine worms that show an interesting strategy of reproduction through a process called epitoky. This process involves the transformation of an immature worm (atoke) into a sexually mature form (epitoke) with specialized swimming and sensory ability which increase the chances of reproductive success [5-7]. All body segments of the epitoke are completely filled with gametes which are released during reproductive swimming. This unique reproductive strategy has caught the attention of many biologists working on Nereidids, making it a model animal for reproductive studies.

The reproductive biology of the Nereidids has long been studied not only for the biological aspects but also for the conservation and propagation of the species [6-11]. However, most studies are limited to only a few Nereidid species and mostly focus on Platynereis dumerilii (Pl. dumerilii). Platynereis dumerilii has currently emerged as the leading model animal in 


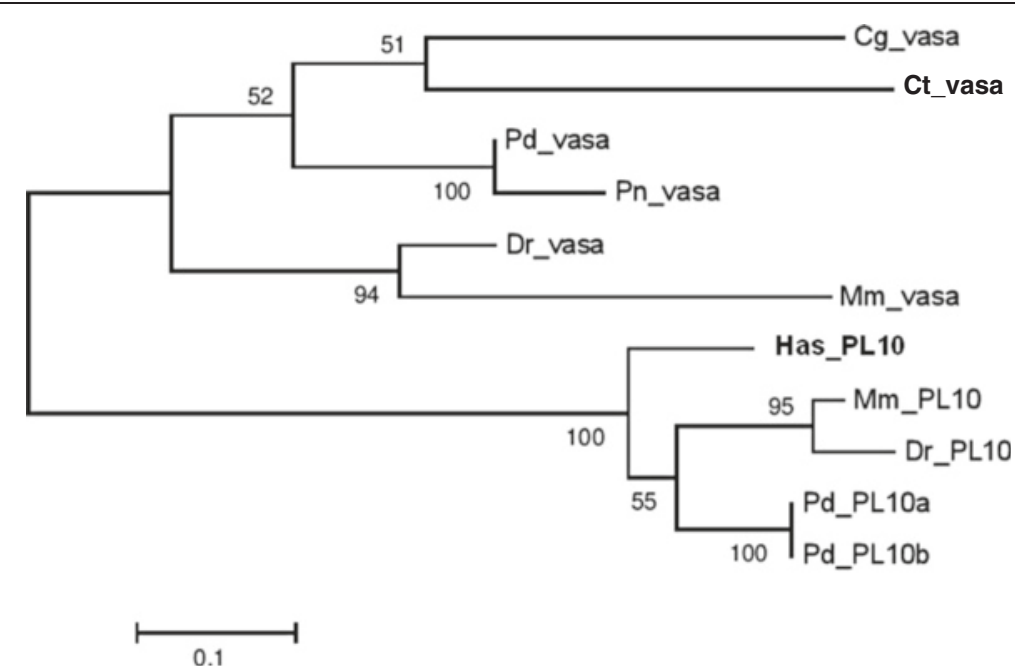

Fig. 1 Phylogenetic analysis of Pn-vasa. Phylogenetic tree constructed by a maximum likelihood method showing orthology of Pn-vasa. Species abbreviations: Cg, Crassostrea gigas; Ct, Capitella teleta; Pd, Platynereis dumerilii; Pn, Perinereis nuntia; Dr, Danio rerio; Mm, Mus musculus; Has, Haliotis asinina. The number on the nodes corresponds to the bootstrap support values. Distance scale represents the number of differences between sequences (e.g. 0.1 means $10 \%$ differences between two sequences)

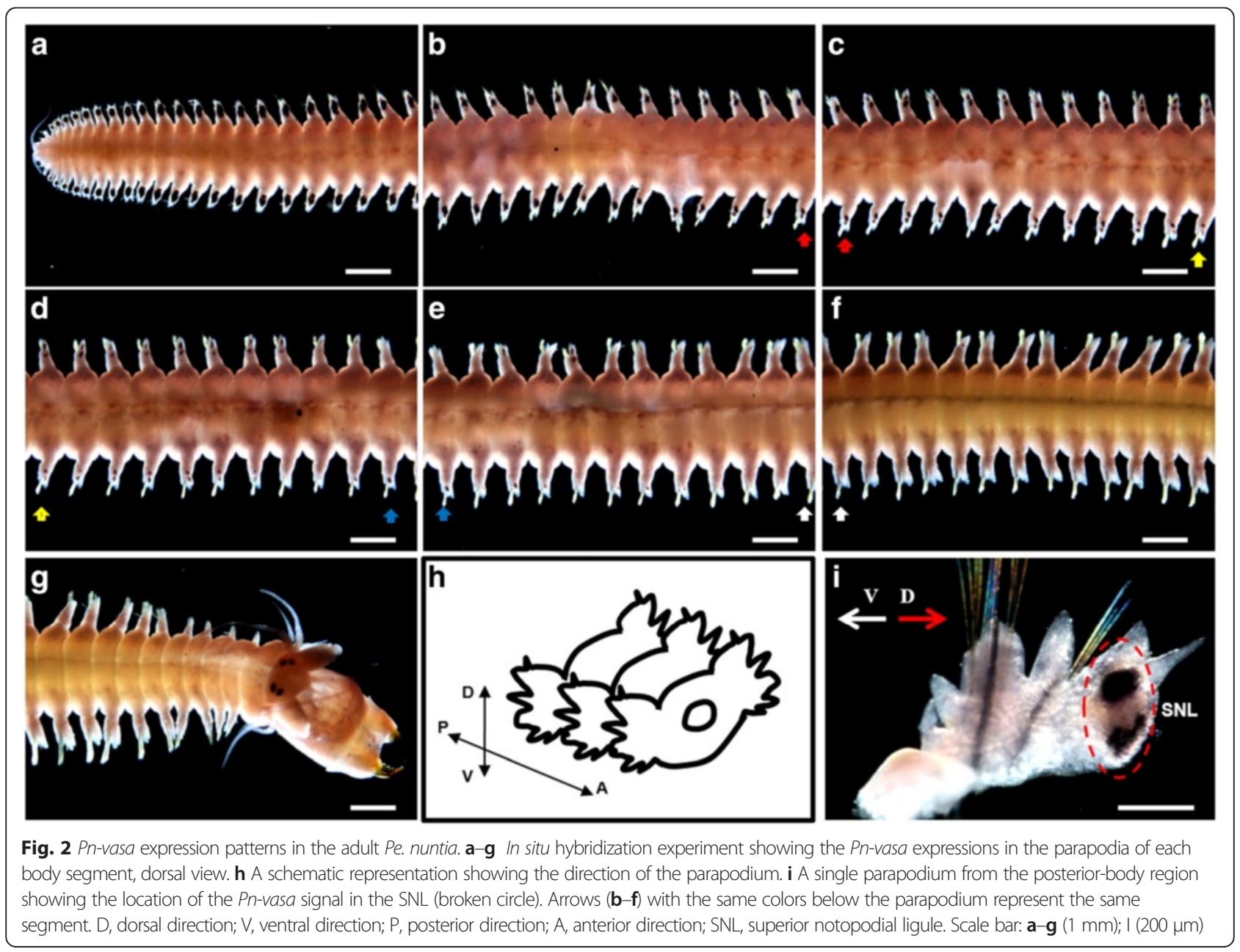


the clade Errantia and is described as a homonomous segmented species $[1,3]$ but with incomplete intersegmental septa [12]. A recent study using a molecular germline marker to trace gamete generation in this species showed that germ cells originate from the mesodermal posterior growth zone (MPGZ) and migrate into the anterior segments to form a transverse cluster of cells in the neck region. This region was then referred to as the primary gonad which produces gamete to fill a large part of the body [13].

Unlike the well-studied $\mathrm{Pl}$. dumerilii, the gamete production mechanism in other Nereidid groups, that have body segments separated by complete intersegmental septa, has never been identified. This group of polychaetes may have developed some unique mechanisms for gamete production in each body segment, which are different from that of $\mathrm{Pl}$. dumerilii. Further study of this mechanism, together with the mechanism already observed in other groups with incomplete septa such as $\mathrm{Pl}$. dumerilii, will provide a better understanding of the ancestral mechanism of gamete production in Annelids.

Our results suggest a new mechanism for gamete production in Pe. nuntia, using vasa as a putative germ cell marker. The Pn-vasa signal was detected in all body segments during the growth of Pe. nuntia from larva to adult. The site of expression changed from the distal end of the parapodium to the inner coelomic cavity in accordance to the growth of segments. We hypothesize that primordial germ cells (PGCs) are supplied from the pygidium to every newly-generating segment.

\section{Materials and methods \\ Animals}

The Nereidid polychaete worms, Pe. nuntia, were purchased from the commercial hatchery in Oita Prefecture, Japan. They were maintained in the Kyushu University Fishery Research Laboratory based on the culture methods employed by the hatchery. Embryos that were raised in plastic containers supplied with running filtered seawater were observed during their developmental stages as described in [8] and [14]. The identification of this species was based on the taxonomic descriptions provided by Glasby and Hsieh [15].

\section{cDNA cloning and molecular phylogeny of Pn-vasa gene}

The total RNA was extracted from the unfertilized eggs of Pe. nuntia using the RNeasy Plant Mini kit (Qiagen). The complementary DNA was generated from this RNA using a PrimeScript RT-PCR kit (Takara). Two degenerate primers (forward: $5^{\prime}$-atcaactttgacaaatacga- 3 '; reverse: $5^{\prime}$-gcgctgaacatsagygtctg-3') were designed based on the
Pdu-vasa mRNA sequence reported by Rebscher et al. [13] (Genbank Acc. No. AM048812.1). Primers were designed corresponding to the highly conserved regions within the coding region of the vasa transcript. The resulting PCR product (619 bp) was cloned into pGEMT-easy vector (Promega) and sequenced. Homology searches were performed using BLASTn in the NCBI database.

Molecular phylogenetic analysis was performed as follows: Related sequences were retrieved from public databases based on BLAST searches and prior knowledge. Multiple alignments of related amino acid sequences were created and a phylogenetic tree was constructed by maximum likelihood using the WAG + I model selected by the Akaike Information Criterion. Alignment, model selection and tree construction was performed with MEGA 5.0 [16]. Five hundred bootstrap pseudoreplicates were performed to evaluate the confidence for each node. PL10 genes from various groups of species were included in the analysis as an out-group.

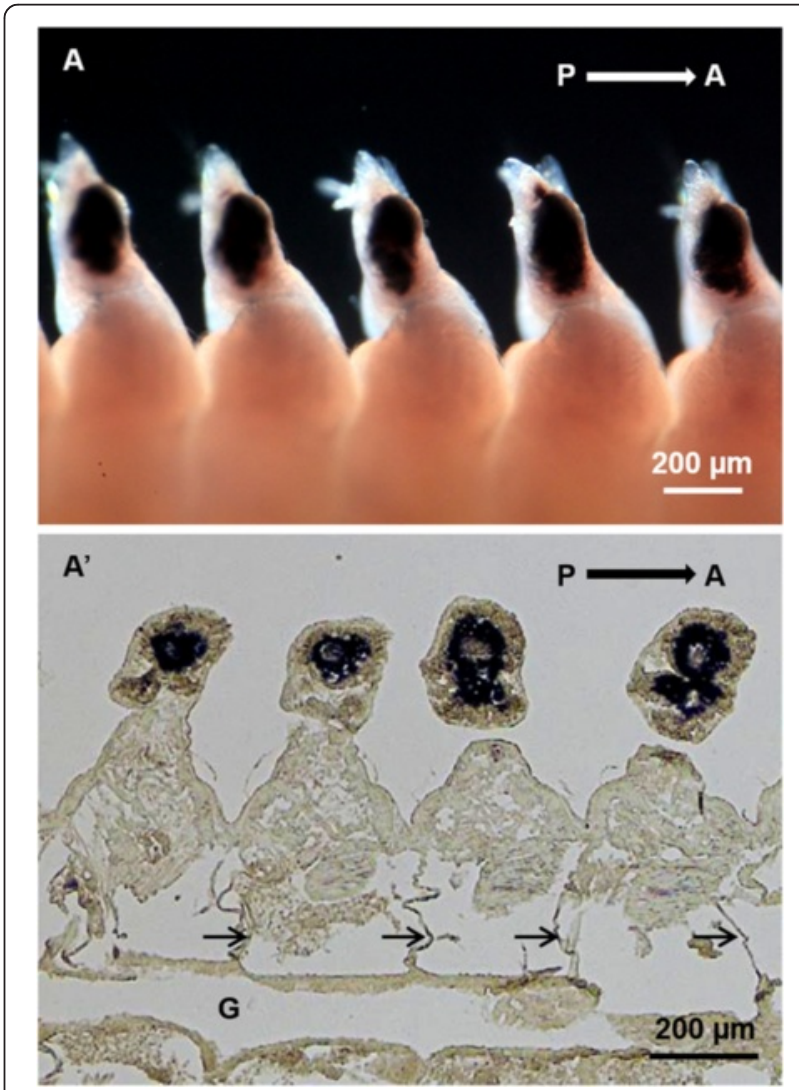

Fig. 3 Pn-vasa mRNA in the parapodia of the posterior-body region of the adult worm. A Hybridized worm showing the Pn-vasa strong expressions in the parapodia, dorsal view. $\mathbf{A}^{\prime}$ Coronal section of (A) showing the position of a big cell cluster in each parapodium. Arrows indicate the septum. P, posterior direction; $A$, anterior direction; $\mathrm{G}$, gut 


\section{In situ hybridization}

Pn-vasa plasmid clones were used as a template to synthesize both sense and anti-sense RNA probes by in vitro transcription using the DIG RNA labeling kit (Roche). Juveniles and adult worms were relaxed for 2-5 min in $0.3 \%$ ethylene glycol monohexyl ether in seawater and then fixed overnight at $4{ }^{\circ} \mathrm{C}$ in $4 \%$ formaldehyde in phosphate buffered saline (PBS). The fixative was rinsed off by washing twice with PBS, and specimens were dehydrated in a series of methanol in PBS and stored in $-20{ }^{\circ} \mathrm{C}$ until use. Whole-mount in situ hybridization was performed as described in the polychaete Chaetopterus [17] with some modifications. Embryos and larvae were treated in the same way as the juvenile and adult worms except that anesthetic was omitted. Proteinase $\mathrm{K}$ treatment was reduced from $20 \mathrm{~min}$ at $37{ }^{\circ} \mathrm{C}$ in juveniles and adults to $5 \mathrm{~min}$ at room temperature in embryos and $10 \mathrm{~min}$ at room temperature in larvae. After in situ hybridization, an immuno-reaction was induced using the anti-DIG alkaline phosphatase conjugated Fab fragment
(Roche) and visualized by the corresponding substrate, Nitro Blue Tetrazolium/5-Bromo-4-chloro-3-indolyl phosphate (NBT/BCIP).

\section{Histology}

Hybridized adult worms were fixed with $4 \%$ paraformaldehyde overnight at $4{ }^{\circ} \mathrm{C}$, dehydrated in series of ethanol, embedded in the paraffin and sliced into $7 \mu \mathrm{m}$ thick sections. The sections were then deparaffinized, mounted, analyzed and photographed under the microscope. Another set of adult worm samples were also prepared for normal hematoxylin and eosin $(\mathrm{H}$ and $\mathrm{E})$ stain following the same procedure as mentioned above, except that samples were fixed with Davidson's fixative instead of $4 \%$ paraformaldehyde.

\section{Results}

To determine the spatial and temporal expression patterns of Pn-vasa in the Nereidid Pe. nuntia at different
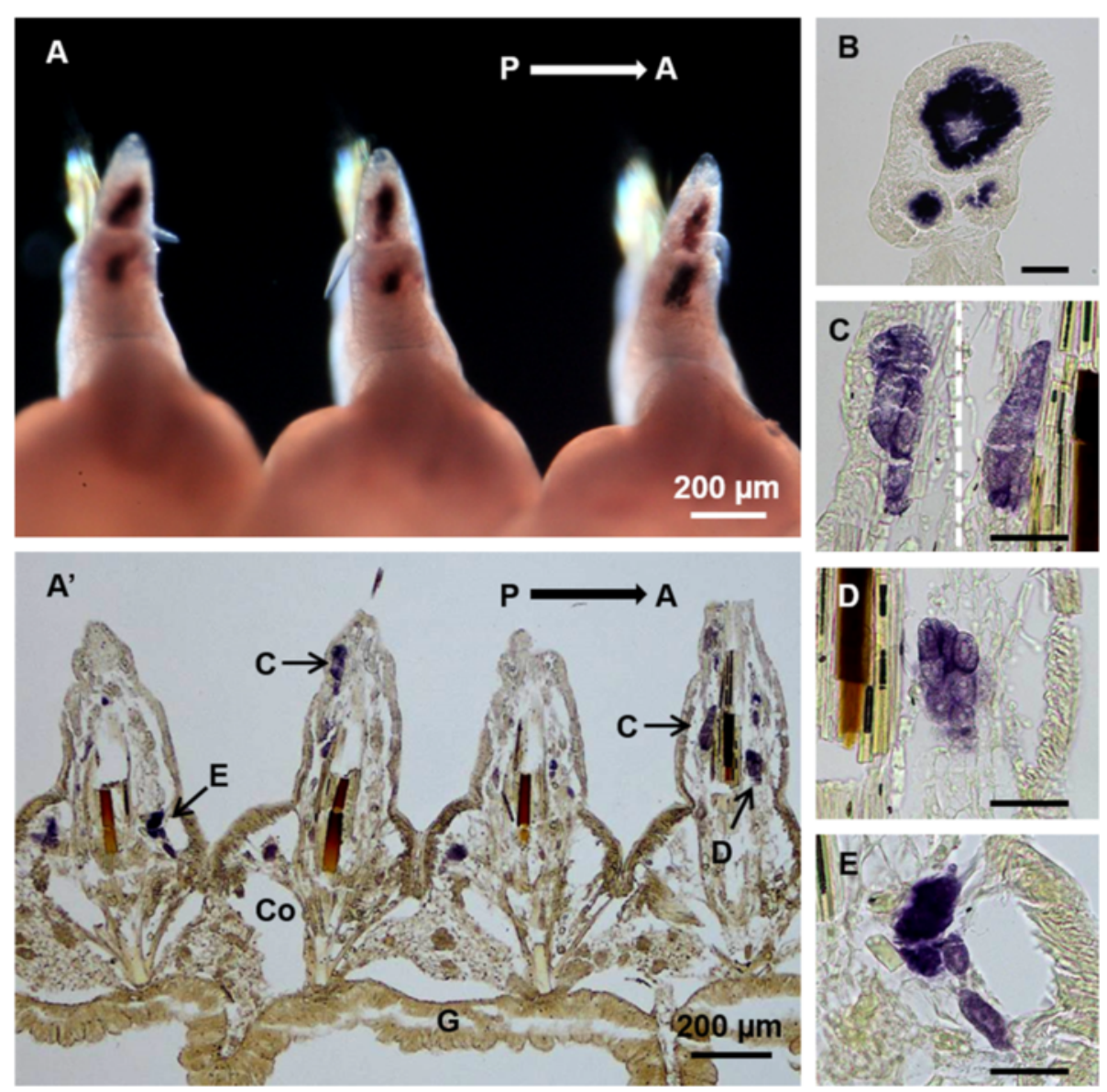

Fig. 4 Pn-vasa mRNA in the parapodia of the mid-body region of the adult worm. $\mathbf{A}$ Hybridized worm showing the weak vasa expressions in the parapodia, dorsal view. $\mathbf{A}^{\prime}$ Coronal section of (A) showing the distribution of the Pn-vasa positive cells in the parapodia and in the coelomic cavity (Co). B A single parapodium showing a large cell cluster and smaller cell clusters. C-E Cell clusters of various forms with Pn-vasa signals. P, posterior direction; A, anterior direction; G, gut. Scale bar: B-E (50 $\mu \mathrm{m})$ 
developmental stages, we performed a whole-mount in situ hybridization experiment using vasa as a molecular germline marker.

Vasa is an ATP-dependent RNA helicase gene of the DEAD-box family, essential for germ cell development [18-23]. This gene was originally identified in Drosophila and was revealed to have a highly conserved role among different organisms [24-39]. Since then, vasa has been used as a molecular marker to study germ cell development in many animals including polychaetes [13, 32-34]. To date vasa expressed not only in germ cells but also in somatic stem cells as well [40-42].

\section{Pn-vasa cDNA cloning and phylogenetic analysis}

A 619 bp cDNA fragment was amplified, cloned and sequenced from the unfertilized egg of the mature worm and used as an anti-sense probe for the in situ hybridization experiment. The amino acid sequence showed $90 \%$ identity to a previously reported complete sequence of $\mathrm{Pl}$. dumerilii vasa mRNA [13] and more than $60 \%$ sequence identity to other known vasa homologues from different annelid species such as in Urechis unicinctus (JQ665715.1), Capitella teleta (BK006523.1), Enchytraeus japonensis (AB306293.1) and Tubifex tubifex (AB257139.1). Molecular phylogenetic analysis showed that Pn-vasa formed a monophylogenetic clade with vasa homologues of other species and was closely related to the DEAD box helicase PL1O genes (Fig. 1).

\section{Pn-vasa expression patterns in adult during oogenesis}

In the adult Nereidid polychaete worm, Pn-vasa mRNA was detected in the dorsal parapodia on both sides of nearly all body segments. The intensity of the Pn-vasa signal was strongest at the most posterior-region and gradually decreased along the mid-body until no signal was detected towards the most anterior-region (Fig. 2a-g). Interestingly, $P n$ vasa was only detected in the superior notopodial ligule (SNL) of the parapodium (Fig. 2i).

Histological examinations revealed that in the posterior-body region, Pn-vasa was strongly expressed in a population of cells in each parapodium (Fig. 3A, A'). In the mid-body region, the Pn-vasa signal was detected in cell clusters of various forms based on their location from the distal end of the parapodium
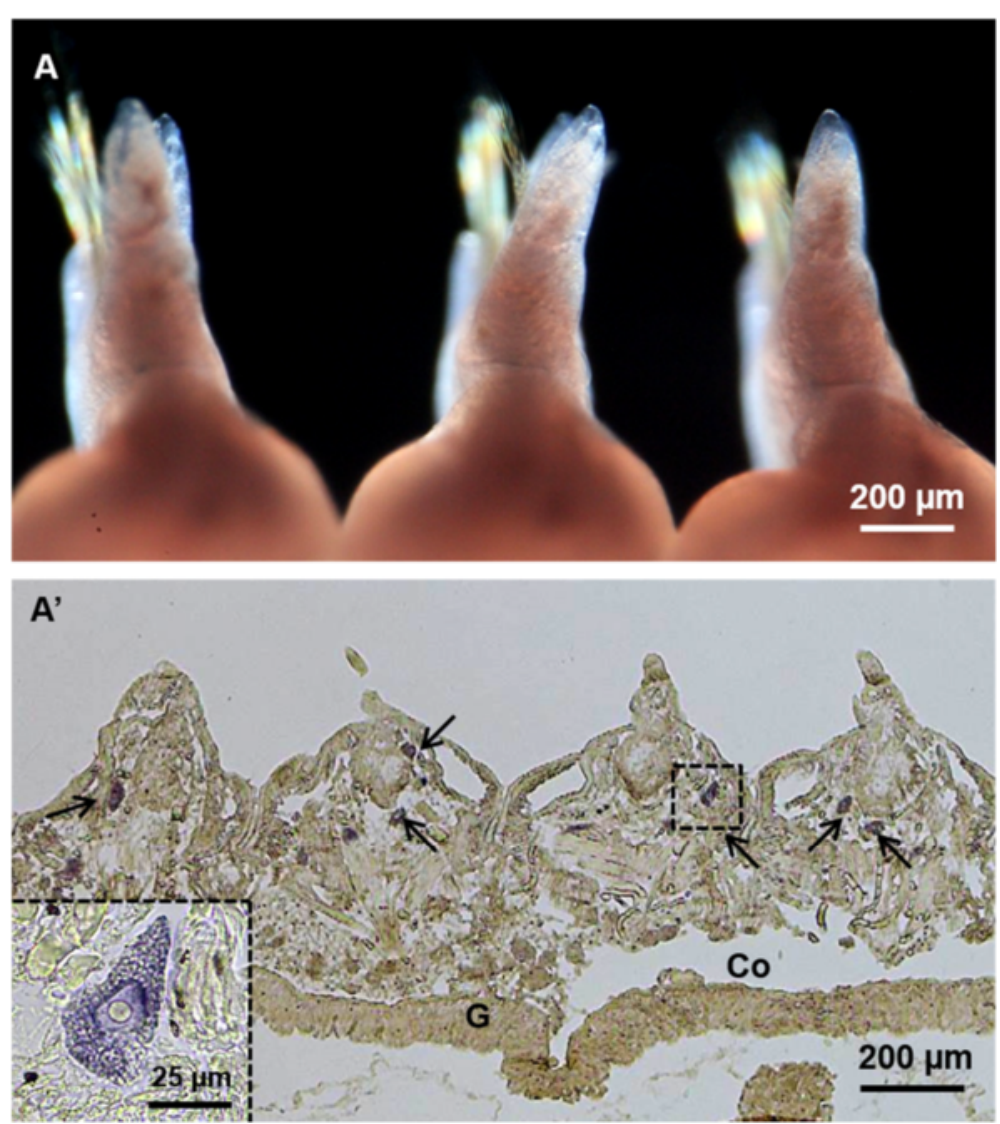

Fig. 5 Pn-vasa mRNA in the parapodia of the anterior-body region of the adult worm. A Hybridized worm with no apparent Pn-vasa expression in the parapodia, dorsal view. A' A coronal section of (A) showing the distribution of Pn-vasa positive cells (arrows, inset) in the coelomic cavity (Co). G, gut 
to the coelomic cavity (Fig. 4A, A'). Most of these cell clusters had an elongated form with strong Pn-vasa signals throughout the entire cell (Fig. 4C-E). In the anterior-body region, Pn-vasa was detected in single cells (Fig. 5A, arrows) that had strong Pn-vasa signals throughout the entire cell (Fig. 5A', inset). Most of these cells were found in the coelomic cavity (Fig. 5A').

To determine the stages of Pn-vasa positive cells (Fig. 6a, d, g, j), we conducted a histological observation of the cells using hematoxylin and eosin stains (Fig. 6c, f, i, l). In the distal area of the parapodium, the big cell cluster (Fig. 6a-b) is composed of cells with condensed chromosomes and pink-colored granular-like structures (Fig. 6c). In the trunk area of the parapodium, the cell clusters had an elongated shape, while the cells inside the cluster also contained condensed chromosomes (Fig. 6f, i). In the coelomic cavity, the cells were larger than those cells in the parapodial area with no visible chromosomes in the nucleus (Fig. 6l). The corresponding sense control experiment is shown in Fig. 6e, h, k .

\section{Pn-vasa expression patterns in embryos and larvae}

During embryogenesis, Pn-vasa mRNA was detected in the surface area of the fertilized egg (Fig. 7A, A'). It was then detected in the $\mathrm{CD}$ cell at the two-cell stage (Fig. 7B, B') and in the D cell at the four-cell stage (Fig. 7C, C'). At $65 \mathrm{~h}$ post fertilization (hpf), Pn-vasa signal was observed in the posterior end of the larva (Fig. 7D; black arrow). At $72 \mathrm{hpf}$, we observed four somatic cell clusters in a spherical shape (Fig. 8A, asterisks) at the base of each parapodium in segments I and II (Fig. 8A). At the same time, we also observed the emergence of a Pn-vasa-positive cell at the posterior end of the larva (Fig. 8A, box frame). At $96 \mathrm{hpf}$,
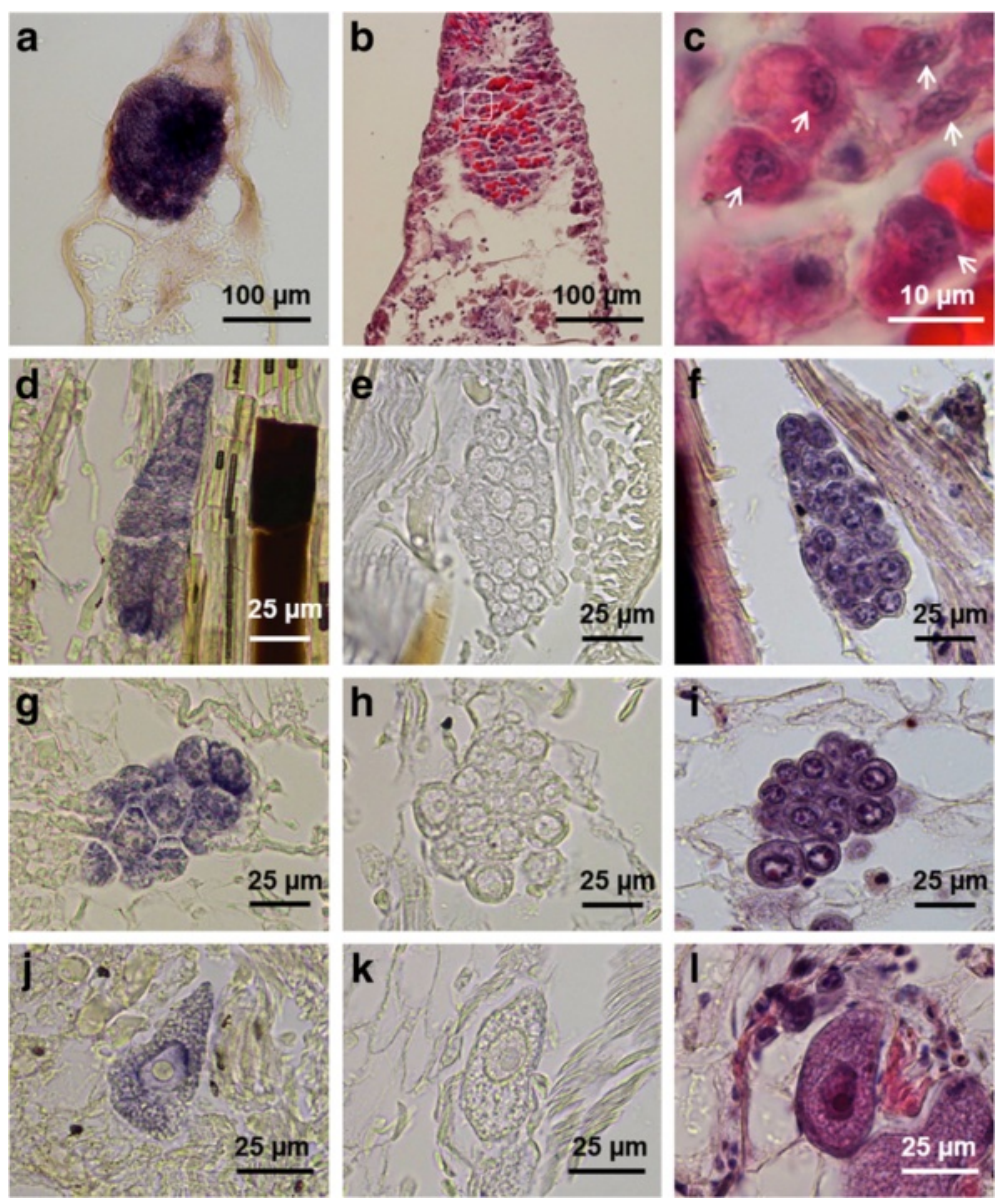

Fig. 6 Germ cell development of Pe. nuntia. a Hybridized slide section showing the Pn-vasa expression in the big cell cluster at the distal end of the parapodium. $\mathbf{d}, \mathbf{g}, \mathbf{j}$ Pn-vasa positive cells observed from the trunk area of the parapodium down to the coelomic cavity. $\mathbf{b}$ Thin section (5 $\mu \mathrm{m})$ of the parapodium stained with hematoxylin and eosin showing the big cell cluster. c Cells from figure $\mathbf{b}$ (box frame) at higher magnification $(1,000 \times)$ showing the cell's condensed chromosomes (arrows) and pink-colored granular-like structures. $\mathbf{f}, \mathbf{i}$, I The corresponding hematoxylin and eosin stain of the Pn-vasa positive cells. Condensed chromosomes are visible in cell clusters (f $\mathbf{f}$ and $\mathbf{i})$. e, $\mathbf{h}, \mathbf{k}$ Sense control experiment. Note: Figure $\mathbf{d}$ is taken from Fig. 4C, while figure $\mathbf{g}$ is taken from other parapodium source. Figure $\mathbf{k}$ is also taken from Fig. 5 (inset) 

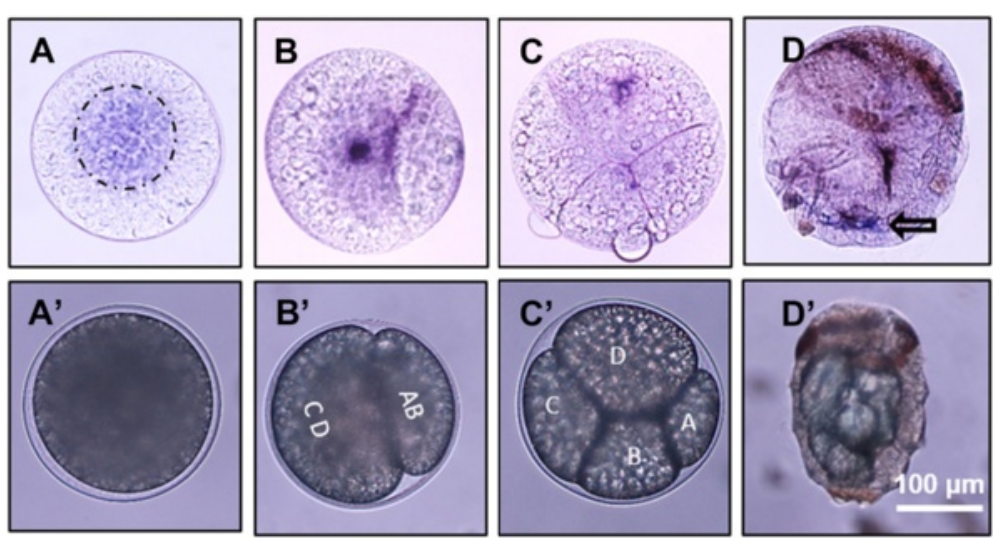

Fig. 7 Pn-vasa mRNA in embryos and larva. A Fertilized egg showing the Pn-vasa signal in the surface area, top view. B At 2-cell stage, Pn-vasa is expressed in the CD-cell quadrant. C At 4-cell stage, Pn-vasa is only expressed in the D-cell quadrant. D At 65 hpf, dorsal view, Pn-vasa is strongly expressed in the most posterior region (black arrow). The anterior region of the larva is characterized by the presence of a mesodermal band which contains the pigment cells [46]. Scale bar: A-D $(100 \mu \mathrm{m})$

Pn-vasa positive cells were found closer to the somatic cell clusters (Fig. 8B, asterisks) in segments I and II.

\section{Pn-vasa expression patterns in nectochaete larvae and juveniles}

In 3-segmented nectochaete worms $(6$ days post fertilization, dpf), Pn-vasa was detected in the parapodia on both sides of segments I and II, at the exact place where the $P n$-vasa-positive cells were found closer to the somatic cell cluster during the larval stage (Fig. 8C, D). No Pn-vasa signal was detected in the future peristomium segment (Fig. 8C, D). At this stage, we also observed the emergence of two Pn-vasa-positive cells positioned in the pygidium (Fig. 8C, C'). In 4-segmented nectochaete worms (8 dpf), four $P n$-vasa positive cells were observed in the pygidium (Fig. 8D, D') while two other Pn-vasa positive cells were found on both sides of the newly-generated segment (Fig. 8D, box frame; inset). In 8-segmented juveniles (10 $\mathrm{dpf}), P n$-vasa signal in the parapodia was stronger in the older segments (segments I and II) and became weaker towards the younger segments (segments III-VIII) (Fig. 9A). Another $P n$-vasa signal was also observed in the anterior border of the pygidium aside from the Pn-vasa positive cells localized in the pygidium (Fig. 9A", arrows).

\section{Discussion}

\section{Pn-vasa expression in the parapodia of Pe. nuntia}

Pn-vasa mRNA was expressed in the parapodia, where signal intensity changed according to the growth of the segments. More intense signals were found in the younger parapodia of the posterior-body region and gradually decreased along the mid-body until a signal was undetectable in the anterior-body region. The strong $P n$-vasa signal in the parapodia of the posterior region was due to the large aggregates of cell clusters (Fig. 3A') in each parapodium. From the posterior to mid-body regions, these large cell clusters in the parapodia appeared to divide into smaller cell clusters (Fig. 4A, arrows $\mathrm{C}-\mathrm{E}$ in Fig. 4A'). The more elongated form and the position of these smaller clusters are consistent with the idea that the clusters migrate from the distal areas of the parapodia to the coelomic cavity where they began the process of oogenesis (Fig. 4B-E). In the anterior-body region (Fig. 5A, A'), nearly all cell clusters in the parapodia had already disappeared, however, Pn-vasa signals were observed in single cells that looked like oocytes in the coelomic cavity (Fig. 5A, arrows; inset). These series of observations may suggest that PGCs settle in the parapodium as a single cell, proliferate to form a large germ cell cluster (Fig. 3A, A'), separate from a large cell cluster into smaller clusters (Fig. 4A, $\mathrm{A}^{\prime}$ ) and migrate into the coelomic cavity to develop into oocytes (Fig.5A').

The existence of a germ cell production site in the Nereidid polychaete was reported in Pl. dumerilii [13] where one primary gonad was found located in the neck region. In contrast, in the present study, the large cell cluster with a strong Pn-vasa signal was observed in the parapodia of each body segment. The presence of these cell clusters in the parapodia may indicate the presence of a gonad of $P e$. nuntia. Although the molecular mechanism underlying the difference in gonad location between these two closely-related species is not yet known, this may be morphologically related to the difference in their septum formation. In $\mathrm{Pl}$. dumerilii, the incomplete septum [12] allows the translocation of PGCs to the neck region, and, subsequently, expansion of germ cells in the whole coelomic cavity as one common compartment [13]. While on the other hand, Pe. nuntia has a complete septum between segments (Additional file 1: Figure S1), thus, each segment has 

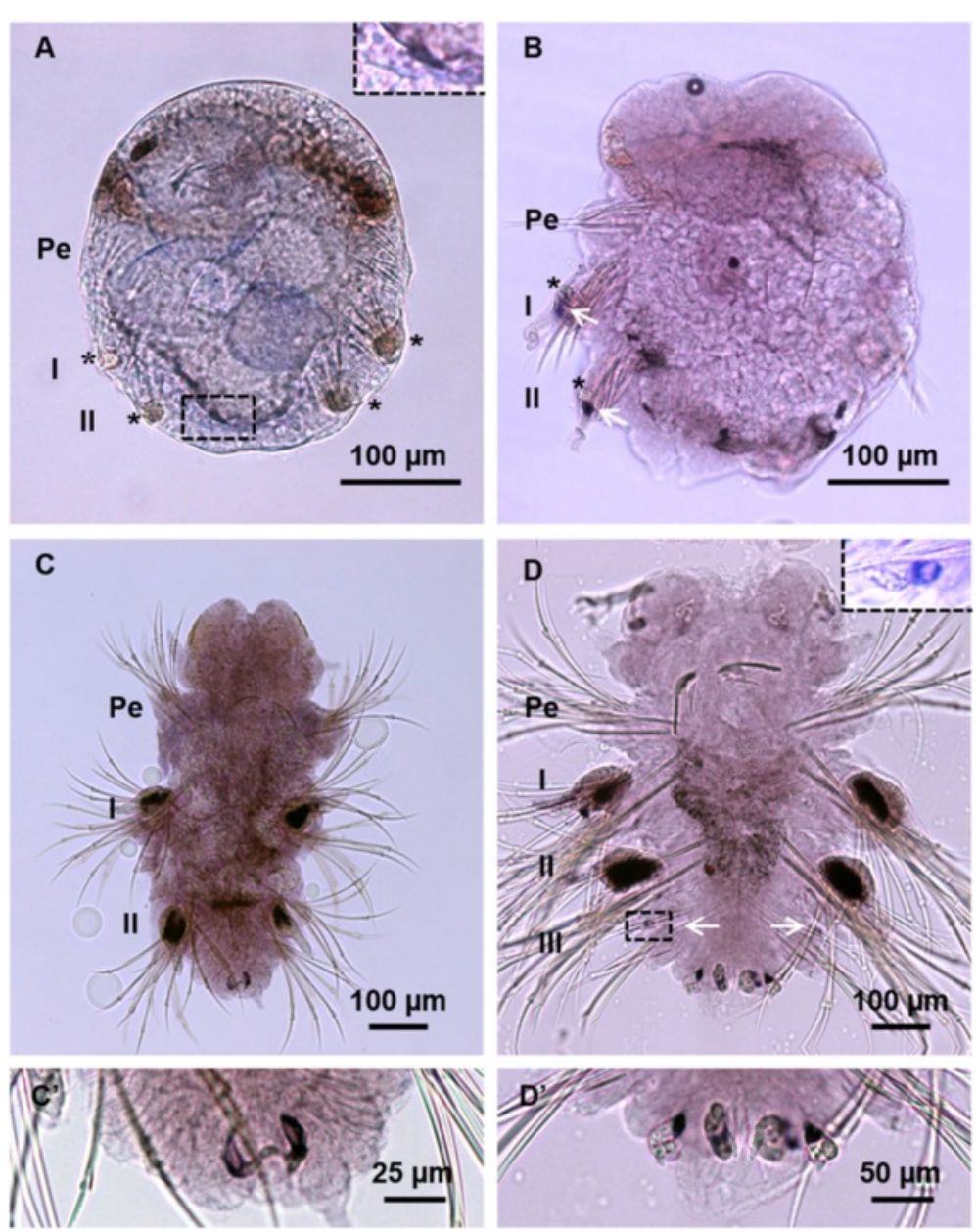

Fig. 8 Pn-vasa expression patterns in larva and juvenile. A Larva at 72 hpf showing the presence of four somatic cell clusters in segments I and II (asterisks) and a small Pn-vasa positive cell at the most posterior end (box frame, inset). B In the 3-segmented worm at 4 dpf, Pn-vasa positive cells (arrows) found closer to the somatic cell clusters (asterisks) at the anlage of the parapodia. C At 5 dpf, Pn-vasa is expressed in the parapodia in segments I and II and Pn-vasa also expressed in two cells in the pygidium (C'). $\mathbf{D}$ In the 4-segmented worm, four Pn-vasa positive cells are found in the pygidium ( $\left.D^{\prime}\right)$ and two small Pn-vasa positive cells are also found on both sides of the newly generated segment (D arrows; inset). No signal found in the future peristomium (Pe). Note: the right side of the parapodial segments in figure $\mathbf{B}$ is behind the worm's body. In figure D (inset), the cell is taken using higher magnification (400x) and at different focal plane

to be equipped with sites for germ cell generation. The original settling area of Pn-vasa positive cells in each parapodium may act as the primary gonad of $P e$. nuntia.

\section{Expression of Pn-vasa in the embryo of Pe. nuntia}

It has been shown that the modes of maternally supplied vasa mRNA distribution in the early stages of embryo vary among animals [23, 30, 32-35]. Here, we observed that this mode also varies in a closely related species in polychaetes. In $\mathrm{Pl}$. dumerilii vasa mRNA was uniformly distributed in early cleavage stages and later found in the micromeres, including the mesoblast $4 \mathrm{D}$ at 38-cell stage [13]. In the present study, Pn-vasa signal appeared to be restricted in the surface area of the fertilized egg (Fig. 7A). This may be the area described as yolk-free cytoplasm in Pl. dumerilii [13]. During the four cell stage, Pn-vasa mRNA was localized into the D cell quadrant, a similar pattern of expression observed in other polychaete species such as Tubifex tubifex [32]. At $65 \mathrm{hpf}, P n$-vasa signal was then localized at the posterior end of the larva (Fig. 7D, arrow). This posterior end was described as the MPGZ in Pl. dumerilii, where Pdu-vasa was also localized at $48 \mathrm{hpf}$ [13].

\section{Germ cell development in Pe. nuntia}

In Pl. dumerilii, PGCs migrate from the MPGZ towards the primary gonad in the neck region during 

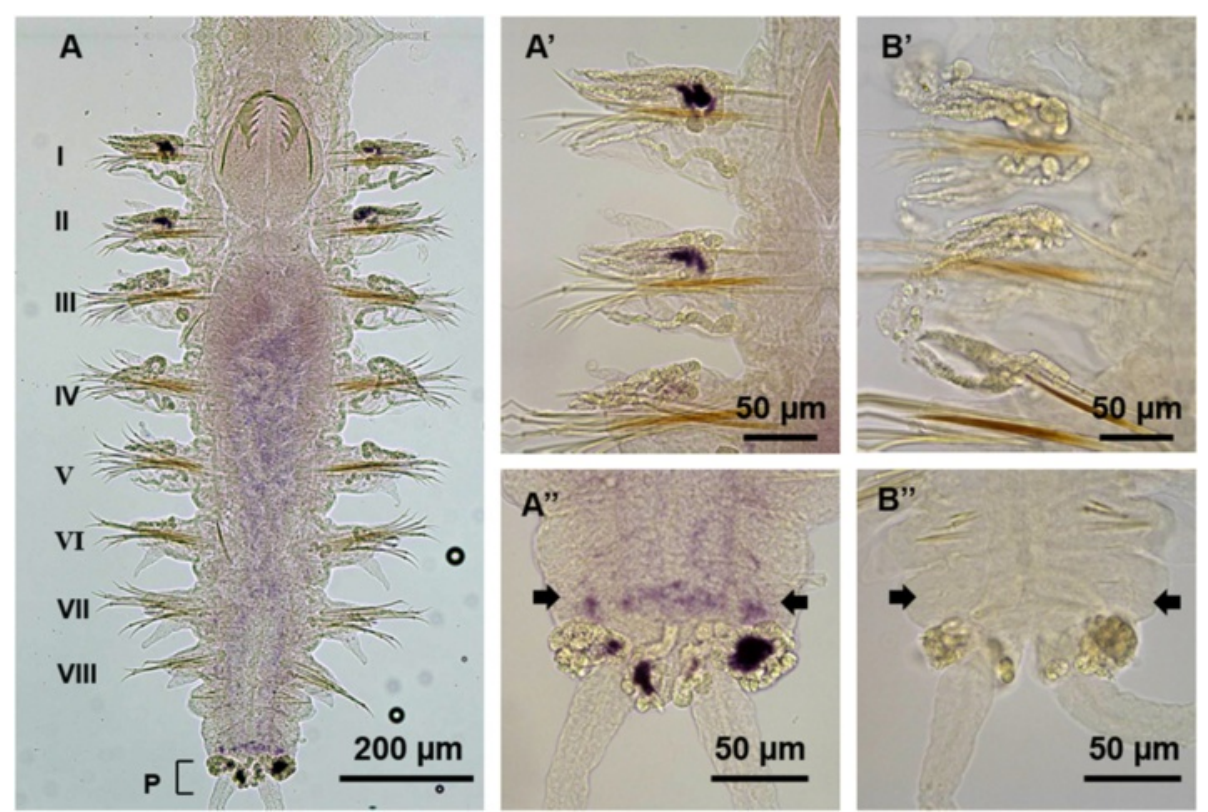

Fig. 9 Pn-vasa mRNA in the juvenile worm. A Pn-vasa signal is strongly expressed in the older segments, I and II and becomes weaker towards the younger segments (Segment III-VIII). $\mathbf{A}^{\prime}$ Parapodia of $(\mathbf{A})$ showing the strong hybridization signals in older segments I and II with the sense probe experiment $B^{\prime}$. A" Posterior end of (A) showing the more intense Pn-vasa signals in the pygidium (P) and another Pn-vasa signals detected in the anterior border of the pygidium (A", arrows). (B") Sense probe experiment. Pe, peristomium or Ce, cephalic segment

the late larval stage [13]. In the present study, we did not observe any vasa signal in the neck region nor traversing cells with vasa signals from the posterior region (Figs. 8 and 9). Instead, we observed Pn-vasa positive cells located beside the somatic cell clusters at the anlage of the parapodia during the early larval stage (Fig. 8B, arrows). In 3-segmented nectochaete worms, two Pn-vasa positive cells were observed in the pygidium (Fig. 8C, $\mathrm{C}^{\prime}$ ). During the addition of a new segment, four Pn-vasa positive cells were observed in the pygidium (Fig. 8D, D') while two other Pn-vasa positive cells were found in the newly-generated segment (Fig. 8D, arrows; inset). These observations may indicate that the Pn-vasa positive cells divide in the pygidium and daughter cells are supplied to both parapodia of the newly-generated segment.

In many animals including polychaetes, vasa has been reported to express in the somatic stem cells [22, 27, 40-42] which has led to a hypothesis that both PGCs and stem cells share some common molecular signatures [40-44]. In Pl. dumerilii, Pdu-vasa was shown to express in these two distinct cell populations: PGCs and somatic stem cells, in the MPGZ during the larval stage [13, 42]. This MPGZ was also described as the segment addition zone [40] or segment/pygidium boundary [45] in other reports. Only PGCs from this zone migrate to the neck region and form the germline of $\mathrm{Pl}$. dumerilii [13]. Whereas somatic stem cell populations are believed to be responsible for the formation of new segments [40].
In the present study, we also observed Pn-vasa signals in the boundary area between the newly-generated segment and the pygidium during the juvenile stage in addition to Pn-vasa positive cells localized in the pygidium (Fig. 9). With this observation, we hypothesize two possible mechanisms for the appearance of Pn-vasa positive cells in the parapodium. One possibility may be that Pn-vasa positive cells from the pygidium migrate to the MPGZ and settle in the parapodium of the newly-generated segment. The MPGZ may act as a queuing area for Pn-vasa cells and may double as an area for somatic stem cell populations to generate new segments. A second possibility is the spontaneous emergence of $P n$-vasa positive cells in every new segment without translocation of germ cells from the pygidium. To confirm our hypothesis, we need to perform a more detailed histological observation and analysis using other molecular markers to determine the identity of the cells.

\section{Conclusion}

This study proposed a new mechanism for germ cell development in every segment separated by a complete septum in Pe. nuntia. Pn-vasa was found to express in the cells of the pygidium suggesting that these cells serve as the main source of germ cells. These germ cells are then supplied to every newly-generating segment. This is different from the previously reported mechanism of gamete production in $\mathrm{Pl}$. dumerilii. The difference in the gamete production pattern of these two homonomous 
a

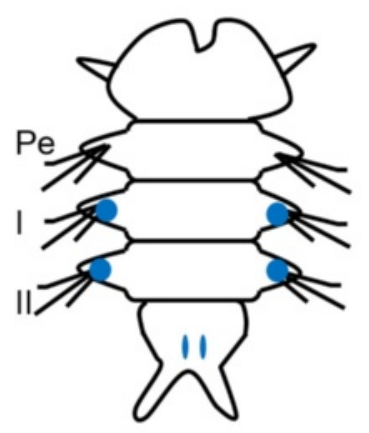

PI. dumerilii

b

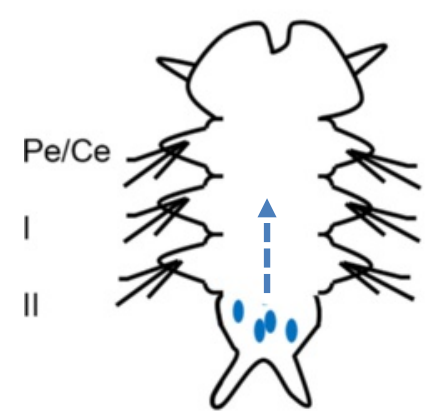

Pe. nuntia
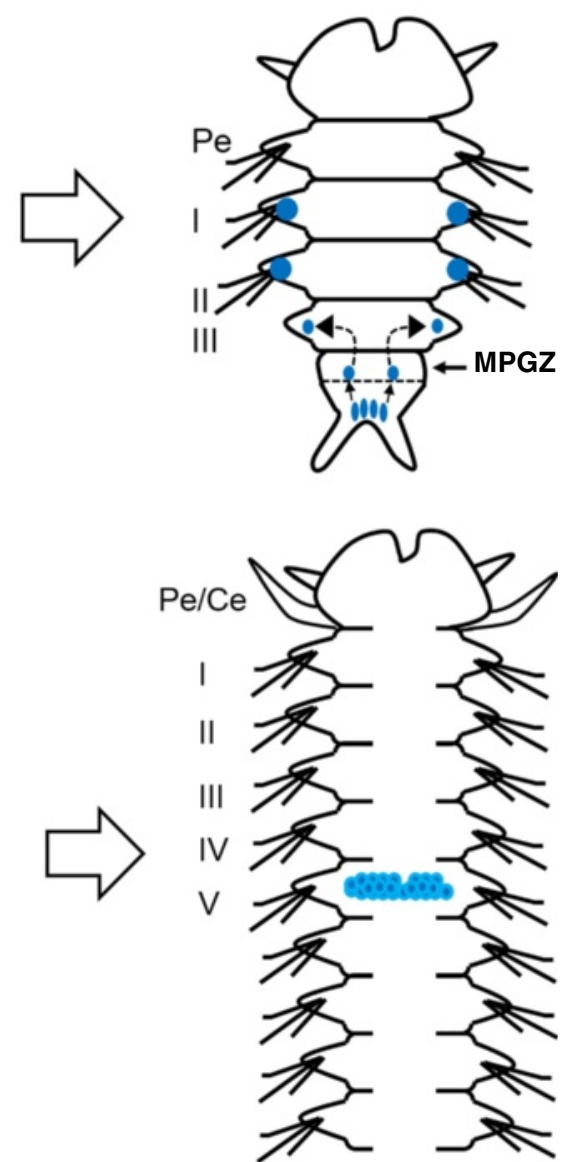

Fig. 10 Schematic diagrams on the mechanisms of germ cell distribution in the Nereidid polychaetes. A Hypothetical germ cell distribution in Pe. nuntia (with complete inter-segmental septa) from the pygidium into each newly-generating segment. B Germ cell distribution in Pl. dumerilii (with incomplete inter-segmental septa) from the MPGZ towards the neck region (fifth segment) during the juvenile stage II [13]

segmented species appears to be related to the presence or absence of a complete septum between segments (Fig. 10). These results provide a fundamental basis for the understanding of the evolutional change in gamete production of polychaetes.

\section{Additional file}

Additional file 1: Figure S1. The morphology of the Inter-segmental septa in the adult $P$. nuntia. Sections show the presence of complete inter-segmental septa (S) in the tail (A), mid-body (B) and anterior-body region $(C)$. Coronal sections, $7 \mu \mathrm{m}$; hematoxylin and eosin stain. (PNG 2009 kb)

\section{Abbreviations}

MPGZ: mesodermal posterior growth zone; PGC: primordial germ cell; SNL: superior notopodial ligule.

\section{Competing interests}

The authors declare that they have no competing interests.
Authors' contributions

MMP and MY designed the experiment; MMP and GP Jr. performed the experiment; MMP, YK, GP Jr. and MY analyzed the results and wrote the manuscript. All authors read and approved the final manuscript.

\section{Acknowledgements}

We thank Mr. Yasunobu Masuo, the polychaete hatchery owner in Oita Prefecture, Japan for sharing his instruction and technical expertise on the proper handling and keeping of the animals used in this study. We also thank Mr. Vladimir Greshishchev for his time and contribution in editing the manuscript.

\section{Author details}

${ }^{1}$ Fishery Research Laboratory, Kyushu University, 4-46-24 Tsuyazaki, Fukutsu 811-3304, Japan. ${ }^{2}$ Graduate School of Agricultural Science, Tohoku University, 15 Mukai, Konorihama, Oshika, Miyagi 986-2242, Japan.

Received: 21 November 2014 Accepted: 6 November 2015 Published online: 07 December 2015

\section{References}

1. Struck TH, Paul C, Hill N, Hartmann S, Hösel C, Kube M, et al. Phylogenomic analyses unravel annelid evolution. Nature. 2011;471:95-8

2. Weigert A, Helm C, Meyer M, Nickel B, Arendt D, Hausdorf B, et al. Illuminating the base of the annelid tree using transcriptomics. Mol Biol Evol. 2014;31(6):1391-401. 
3. Purschke G. On the ground pattern of Annelida. Org Divers Evol. 2002;:181-96

4. Vinther J, Eibye-Jacobsen D, Harper D. An early Cambrian stem polychaete with pygidial cirri. Biol Lett. 2011;7:929-32.

5. Clark RB. The origin and formation of the heteronereis. Biol Rev. 1961;36:199-236.

6. Giangrande A. Polychaete reproductive patterns, life cycles and life histories: an overview. Oceanogr Mar Biol Ann Rev. 1997;35:323-89.

7. Fischer A. Reproductive and developmental phenomena in Annelids: a source of exemplary research problems. Hydrobiol. 1999;402:1-20.

8. Hardege JD, Bartels-Hardege HD. Spawning behavior and development of Perinereis nuntia var. brevicirrus (Annelida: Polychaeta). Invertebr Biol. 1995;114:39-45.

9. Poltana P, Lerkitkul T, Pongtippatee-Taweepreda P, Asuvapongpattana S, Wongprasert K, Sriurairatana $\mathrm{S}$, et al. Culture and development of the polychaete Perinereis cf. nuntia. Invert Repro Dev. 2007;50:13-20.

10. Eckelbarger KJ. Oogenesis and oocytes. Hydrobiol. 2005;535/536:179-98.

11. Rouse GW, Pleijel F. Polychaetes. Oxford. Oxford University Press; 2001.

12. Fischer A, Dorresteijn AWC. The Polychaete Platynereis dumerilii (Annelida): a laboratory animal with spiralian cleavage, lifelong segment proliferation and a mixed benthic/pelagic life cycle. BioEssays. 2004;26:314-25.

13. Rebscher N, Zelada-González F, Banisch TU, Raible F, Arendt D. Vasa unveils a common origin of germ cells and of somatic stem cells from the posterior growth zone in the polychaete Platynereis dumerilii. Dev Biol. 2007:306:599-611.

14. Fischer AH, Henrich T, Arendt D. The normal development of Platynereis dumerilii (Nereididae). J Exp Zool B Mol Dev Evol. 2010;320:94-104.

15. Glasby CJ, Hsieh H-L. New species and new records of the Perinereis nuntia species group (Nereididae: Polychaeta) from Taiwan and other Indo-West Pacific shores. Zool Stud. 2006;45(4):553-77.

16. Tamura K, Peterson D, Peterson N, Stecher G, Nei M, Kumar S. MEGA5: molecular evolutionary genetics analysis using maximum likelihood, evolutionary distance, and maximum parsimony methods. Mol Biol Evol. 2011;28(10):2731-9.

17. Seaver $\mathrm{EC}$, Paulson DA, Irvine SQ, Martindale MQ. The spatial and temporal expression of Ch-en, the engrailed gene in the polychaete Chaetopterus, does not support a role in body axis segmentation. Dev Biol. 2001;236:195-209.

18. Hay B, Jan LY, Jan YN. A protein component of Drosophila polar granules is encoded by vasa and has extensive sequence similarity to ATP-dependent helicases. Cell. 1988;55:577-87.

19. Linder P. Birth of the DEAD box. Nature. 1989:337:121-2.

20. Schmid SR, Linder P. D-E-A-D protein family of putative RNA helicases. Mol Microbiol. 1992:6:283-91.

21. Liang L, Diehl-Johnes W, Lasko P. Localization of vasa protein to the Drosophila pole plasm is independent of its RNA-binding and helicase activities. Development. 1994;120:1201-11.

22. Raz $\mathrm{E}$. The function and regulation of vasa-like genes in germ-cell development. Genome Biol. 2000;3:1017.1-6.

23. Özhan-Kizil G, Havemann J, Gerberding M. Germ cells in the crustacean Parhyale hawaiensis depend on Vasa protein for their maintenance but not for their formation. Dev Biol. 2009:327:230-9.

24. Lasko P, Ashburner M. The product of the Drosophila gene vasa is very similar to eukaryotic initiation factor-4A. Nature. 1988;335:611-7.

25. Saffman EE, Lasko P. Germline development in vertebrates and invertebrates. Cell Mol Life Sci. 1999;55:1141-63.

26. Komiya T, Itoh K, Ikenishi K, Furusawa M. Isolation and characterization of a novel gene of the DEAD box protein family which is specifically expressed in germ cells of Xenopus laevis. Dev Biol. 1994;162:354-63.

27. Shibata N, Umesono Y, Orii H, Sakurai T, Watanabe K, Agata K. Expression of vasa (vas)-related genes in germline cells and totipotent somatic stem cells of planarians. Dev Biol. 1999;206:73-87.

28. Toyooka Y, Tsunekawa N, Takahashi Y, Satoh M, Noce T. Expression and intracellular localization of mouse Vasa-homologue protein during germ-cell development. Mech Dev. 2000;93:139-49.

29. Chang C, Dearden P, Akam M. Germ line development in the grasshopper Schistocerca gregaria: vasa as a marker. Dev Biol. 2002;252:100-18.

30. Sagawa $K$, Yamagata $H$, Shiga Y. Exploring embryonic germ line development in the water flea, Daphnia magna, by zinc-finger-containing VASA as a marker. Gene Expr Patterns. 2005;5:669-78.
31. Dearden PK. Germ cell development in the honeybee (Apis mellifera); vasa and nanos expression. BMC Dev Biol. 2006;6:6.

32. Oyama A, Shimizu T. Transient occurrence of vasa-expressing cells in nongenital segments during embryonic development in the oligochaete annelid Tubifex tubifex. Dev Genes Evol. 2007;217:675-90.

33. Dill KK, Seaver EC. Vasa and nanos are coexpressed in somatic and germ line tissue from early embryonic cleavage stages through adulthood in the polychaete Capitella sp. I. Dev Genes Evol. 2008;218:453-63.

34. Sugio M, Takeuchi K, Kutsuna J, Tadokoro R, Takahashi Y, Yoshida-Noro C, et al. Exploration of embryonic origins of germline stem cells and neoblasts in Enchytraeus japonensis (Oligochaeta, Annelida). Gene Expr Patterns. 2008;8:227-36.

35. Blázquez M, González A, Mylonas CC, Piferrer F. Cloning and sequence analysis of a vasa homolog in the European sea bass (Dicentrarchus labrax): tissue distribution and mRNA expression levels during early development and sex differentiation. Gen Comp Endocr. 2011;170:322-33.

36. Wang Y, Chen Y, Han K. A vasa gene from green mud crab Scylla paramamosain and its expression during gonadal development and gametogenesis. Mol Biol Rep. 2012;39:4327-35.

37. Kato Y, Nakamoto A, Shiomi I, Nakao H, Shimizu T. Primordial germ cells in an oligochaete annelid are specified according to the birth rank order in the mesodermal teloblast lineage. Dev Biol. 2013;379:246-57.

38. Dansereau DA, Lasko P. The development of germline stem cells in Drosophila. Methods Mol Biol. 2008:450:3-26.

39. Mochizuki K, Nishimiya-Fujisawa C, Fujisawa T. Universal occurrence of the vasa-related genes among metazoans and their germline expression in Hydra. Dev Genes Evol. 2001;211:299-308.

40. Gazave E, Béhague J, Laplane L, Guillou A, Préau L, Demilly A, et al. Posterior elongation in the annelid Platynereis dumerilii involves stem cells molecularly related to primordial germ cells. Dev Biol. 2013;382:246-67.

41. Gustafson EA, Wessel GM. Vasa genes: emerging roles in the germ line and in multipotent cells. Bioassays. 2010;32:626-37.

42. Rebscher N, Lidke AK, Ackermann CF.Hidden in the crowd: primordial germ cells and somatic stem cells in the mesodermal posterior growth zone of the polychaete Platynereis dumerilii are two distinct cell populations. EvoDevo. 2012;3:9.

43. Juliano CE, Swartz SZ, Wessel GM. A conserved germline multipotency program. Development. 2010;137:4113-26.

44. Ewen-Campen B, Schwager EE, Extravour CGM. The molecular machinery of germ line specification. Mol Reprod Dev. 2010;77:3-18.

45. Niwa N, Akimoto-Kato A, Sakuma M, Kuraku S, Hayashi S. Homeogenetic inductive mechanism of segmentation in polychaete tail regeneration. Dev Biol. 2013;381:460-70.

46. Wilson EB. The cell lineage of Nereis. J Morphol. 1892;6:361-466.

\section{Submit your next manuscript to BioMed Central and take full advantage of:}

- Convenient online submission

- Thorough peer review

- No space constraints or color figure charges

- Immediate publication on acceptance

- Inclusion in PubMed, CAS, Scopus and Google Scholar

- Research which is freely available for redistribution 